\title{
PENELITIAN TINDAKAN KELAS: APA DAN BAGAIMANA MELAKSANAKANNYA?
}

Oleh: Triyono

\begin{abstract}
Abstrak
Pada saat ini penelitian tindakan kelas (PTK) menjadi trend di kalangan para guru dan dosen sebagai sebuah upaya untuk memecahkan masalah, memperbaiki situasi, meminimalkan terjadinya miskonsepsi, dan atau meningkatkan kualitas proses pembelajaran. Penelitian tindakan kelas dapat dikategorikan sebagai penelitian kualitatif-eksperimen; karena analisis datanya menggunakan pendekatan kualitatif, dan ada tindakan yang dikenakan terhadap subjek penelitian, serta dilakukan analisis dan evaluasi terhadap hasil yang dicapai setelah dilakukan tindakan. Secara garis besar terdapat empat tahapan yang lazim dilalui dalam PTK yaitu: perencanaan, pelaksanaan, pengamatan, dan refleksi. Keempat tahapan tersebut merupakan tahapantahapan yang membentuk sebuah siklus; dengan demikian, PTK bukan merupakan kegiatan tunggal, akan tetapi selalu berupa serangkaian kegiatan yang akan kembali ke asal dalam bentuk siklus-siklus. Objek yang diteliti dalam PTK dapat berasal dari unsur: siswa, guru, materi pembelajaran, peralatan atau sarana pembelajaran, hasil pembelajaran, lingkungan, atau unsur pengelolaan.
\end{abstract}

Kata kunci: penelitian tindakan, perencanaan, pelaksanaan, pengamatan, refleksi dan evaluasi

\section{Pendahuluan}

Dalam beberapa tahun terakhir, penelitian tindakan kelas (classroom action research) makin menjadi trend untuk dilakukan oleh para dosen dan guru sebagai upaya untuk memecahkan masalah, memperbaiki situasi, dan atau meningkatkan kualitas proses pembelajaran di kelas. Menurut Sunendar (2008), pada awalnya PTK dilakukan dengan tujuan untuk mencari solusi terhadap masalah sosial ---seperti: penggangguran, kenakalan remaja--- yang berkembang dalam masyarakat pada saat itu. PTK dilakukan dengan diawali oleh suatu kajian terhadap masalah tersebut secara sistematik; kemudian berdasarkan hasil kajian tadi, dijadikan dasar untuk mengatasi masalah tersebut.

Sejumlah dokumen yang dikaji, seperti dalam Sulipan (2008) dan Sunendar (2008) menyebutkan bahwa PTK pertama kali diperkenalkan oleh seorang ahli psikologi sosial Amerika yang bernama Kurt Lewin pada tahun 1946. Inti gagasan Lewin inilah kemudian dikembangkan oleh ahli-ahli lain seperti Stephen Kemmis, Robin Mc Taggart, 
John Elliot, dan Dave Ebbutt. Pada awalnya, penelitian tindakan menjadi salah satu model penelitian yang dilakukan pada bidang pekerjaan tertentu, dimana peneliti melakukan pekerjaannya, baik di bidang pendidikan, kesehatan, maupun pengelolaan sumberdaya manusia. Salah satu contoh pekerjaan utama dalam bidang pendidikan ialah mengajar di kelas, menangani bimbingan dan konseling, dan mengelola sekolah. Dengan demikian, yang menjadi subjek penelitian adalah situasi di kelas atau individu siswa dalam kelas. Para guru dapat melakukan kegiatan penelitiannya tanpa harus pergi ke tempat lain seperti para peneliti konvensional pada umumnya. PTK di Indonesia baru dikenal pada akhir dekade 1980-an; dan sampai sekarang ini keberadaan PTK di Indonesia masih sering terjadi 'pro' dan 'kontra'; terutama jika dikaitkan dengan bobot keilmiahannya.

Menurut Elliot (dalam Sulipan, 2008) PTK adalah kajian tentang situasi sosial dengan maksud untuk meningkatkan kualitas tindakan di dalamnya. Pendapat yang hampir senada dikemukakan oleh Kemmis dan Mc Taggart (1988) yang mengatakan bahwa PTK adalah suatu bentuk refleksi diri secara kolektif yang dilakukan oleh peserta-pesertanya dalam situasi sosial untuk meningkatkan penalaran dan keadilan praktik-praktik tertentu maupun terhadap situasi tempat dilakukan praktik-praktik tersebut.

Berdasarkan pendapat-pendapat di atas, jelaslah bahwa PTK dilakukan dalam rangka agar seorang guru bersedia untuk mengintrospeksi, bercermin, merefleksi, atau mengevaluasi dirinya sendiri sehingga kemampuannya sebagai guru bisa ditingkatkan. Untuk selanjutnya dari peningkatan kemampuan diri tersebut dapat berpengaruh terhadap peningkatan kualitas proses dan hasil pembelajaran; baik dalam aspek: penalaran, keterampilan, hubungan sosial, maupun aspek-aspek lain yang bermanfaat bagi siswa. Sebab selama ini kinerja guru dalam menjalankan proses pembelajaran kurang ---kalau tidak boleh dikatakan tidak--- ada yang mengontrol; dalam artian apakah aktivitas yang dijalankan guru dalam kelas sudah benar, sesuai dengan kaidah-kaidah maupun konsep teori pembelajaran yang ideal. 
Dengan dilaksanakannya PTK, berarti guru juga berkedudukan sebagai peneliti, yang senantiasa bersedia meningkatkan kualitas kemampuan mengajarnya. Upaya peningkatan kualitas tersebut diharapkan dapat dilakukan secara sistematik, realistik, dan rasional; dengan cara meneliti semua 'aksinya' di depan kelas sehingga gurulah yang tahu persis kekurangan-kekurangannya. Apabila dalam pelaksanaan 'aksinya' masih terdapat kekurangan, guru tadi diharapkan bersedia melakukan perubahan, perbaikan, dan atau penyempurnaan-penyempurnaan.

\section{Ciri-ciri Penelitian Tindakan Kelas}

PTK mempunyai paradigma tersendiri yang agak berbeda jika dibandingkan dengan jenis penelitian yang lain, misalnya penelitian naturalistik, penelitian eksperimen, penelitian survei, penelitian analisis isi, atau penelitian kebijakan. Jika dihubungkan dengan penelitian yang lain, PTK dapat dikategorikan sebagai jenis penelitian kualitatif-eksperimen. PTK dapat dikategorikan sebagai penelitian kualitatif, karena pada saat data dianalisis digunakan pendekatan kualitatif, tanpa ada perhitunganperhitungan statistik. Dikatakan sebagai penelitian eksperimen, karena PTK diawali dengan perencanaan, adanya perlakuan atau tindakan terhadap subjek penelitian, ada pengamatan, dan adanya evaluasi dan refleksi terhadap hasil yang dicapai setelah dilakukan tindakan.

Ditinjau dari karakteristiknya, Sunendar (2008) menyatakan bahwa PTK setidaktidaknya memiliki ciri-ciri (1) didasarkan pada masalah yang dihadapi oleh guru dalam pembelajaran, (2) adanya kolaborasi dalam melaksanakannya, (3) peneliti sekaligus sebagai praktisi yang melakukan refleksi, (4) bertujuan untuk memperbaiki dan atau meningkatkan kualitas praktik pembelajaran, dan (5) dilaksanakan dalam serangkaian langkah dengan beberapa siklus. Sulipan (2008) mencatat ada tujuh ciri PTK yaitu (1) didasarkan atas masalah yang dihadapi guru dalam pembelajaran, (2) dilakukan secara kolaboratif melalui kerjasama dengan pihak lain, (3) peneliti sekaligus sebagai praktisi yang melakukan refleksi, (4) bertujuan memecahkan masalah atau meningkatkan mutu pembelajaran, (5) dilaksanakan dalam serangkaian langkah yang terdiri dari beberapa 
siklus, (6) yang diteliti adalah tindakan yang dilakukan; meliputi: efektivitas metode, teknik atau proses pembelajaran, termasuk: perencanaan, pelaksanaan, dan penilaian, dan (7) tindakan yang dilakukan adalah tindakan yang diberikan oleh guru kepada peserta didik.

Penulis lain seperti: Winter (dalam Suwarsih Madya, 2008) mengidentifikasi ciriciri PTK ada enam yakni (1) kritik-reflektif, (2) kritik-dialektik, (3) kolaboratif, (4) risiko, (5) susunan jamak, dan (6) internalisasi antara teori dan praktik. Untuk lebih jelasnya, berikut ini dikemukakan secara singkat karakteristik PTK tersebut.

Kritik-reflektif. Salah satu langkah dalam penelitian kualitatif pada umumnya dan khususnya PTK adalah adanya upaya refleksi terhadap hasil observasi mengenai latar dan kegiatan suatu tindakan. Hanya saja, dalam PTK yang dimaksud dengan refleksi ialah suatu upaya evaluasi atau penilaian terhadap tindakan yang dilakukan dan dari hasil refleksi ini perlu adanya kritik sehingga memungkinkan adanya perubahan dan atau perbaikan pada tahap selanjutnya.

Kritik-dialektif. Dengan adanya kritik-dialektif diharapkan peneliti bersedia melakukan pemeriksaan terhadap (a) konteks hubungan secara menyeluruh yang merupakan satu unit walaupun dapat dipisahkan secara jelas, dan (b) struktur kontradiksi secara internal, yang memungkinkan adanya kecenderungan untuk berubah.

Kolaboratif. Di dalam PTK diperlukan hadirnya suatu kerjasama dengan pihakpihak lain seperti: atasan, teman sejawat atau kolega, atau siswa, yang diharapkan dapat menjadi sumber data. Bentuk kerjasama atau kolaborasi di antara para anggota dalam semua situasi dan kondisi itulah yang menyebabkan suatu proses dapat berlangsung. Pandangan yang disampaikan oleh setiap kolaborator terhadap berbagai permasalahan yang muncul merupakan sumbangan yang sangat penting dalam upaya memahami segala permasalahan yang muncul.

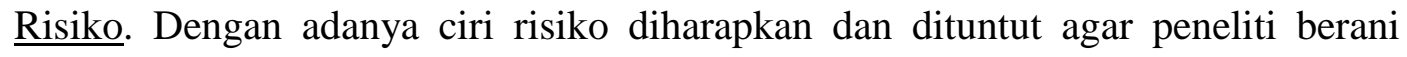
mengambil risiko; terutama pada waktu proses penelitian berlangsung. Risiko yang mungkin ada di antaranya (a) melesetnya hipotesis, dan (b) adanya tuntutan untuk melakukan suatu trasformasi atau perubahan tindakan yang dipilihnya. 


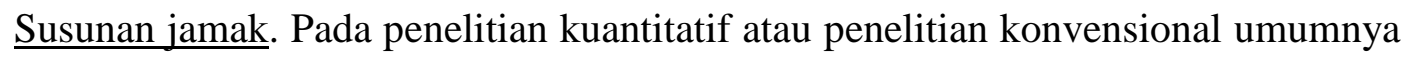
berstruktur tunggal, karena kesimpulan ditentukan oleh penelitinya. Akan tetapi PTK memiliki struktur jamak, karena penelitian ini bersifat dialektik, reflektif, partisipatif, dan melalui kolaboratif. Struktur jamak ini berkaitan dengan pandangan bahwa fenomena yang diteliti harus mencakup semua komponen pokok agar supaya komprehensif. Sebagai contoh, jika yang diteliti adalah situasi dan kondisi proses pembelajaran, maka situasinya paling tidak harus meliputi: aktivitas guru, aktivitas siswa, rumusan kompetensi dasar dan indikator, interaksi pembelajaran, dan hasil pembelajaran yang dicapai.

Internalisasi antara teori dan praktik. Menurut pandangan para ahli PTK bahwa antara teori dengan praktik bukan merupakan dua dunia yang berlainan, akan tetapi keduanya merupakan dua tahap yang berbeda, saling ketergantungan, dan keduanya berfungsi untuk mendukung terjadinya perubahan. Pandangan ini berbda dengan para ahli penelitian konvensional yang beranggapan bahwa antara teori dengan praktik merupakan dua hal yang terpisah.

\section{Jenis dan Model Penelitian Tindakan Kelas}

Menurut Chein (dalam Suwarsih Madya, 2008) dan Sulipan (2008) ada empat jenis PTK, yaitu (1) PTK diagnostik, (2) PTK, partisipan, (3) PTK empirik, dan (4) PTK eksperimental.

PTK diagnostik adalah penelitian tindakan yang dirancang untuk menuntun peneliti ke arah suatu tindakan tertentu. Dalam hal ini, peneliti mendiagnosis dan memasuki situasi yang terdapat dalam latar penelitian. Misalnya, jika peneliti berupaya menangani perselisihan, pertengkaran, atau konflik yang terjadi antarsiswa yang terdapat dalam suatu sekolah atau kelas.

Suatu penelitian tindakan kelas disebut sebagai PTK partisipan apabila orang yang melakukan penelitian terlibat secara langsung dalam proses penelitian sejak awal sampai dengan hasil penelitian berupa laporan. Dengan demikian, sejak perencanaan, peneliti 
senantiasa terlibat; demikian pula pada saat memantau, mencatat, mengumpulkan dan menganalisis data, sampai penyusunan laporan.

PTK empirik adalah penelitian tindakan kelas yang dilaksanakan dengan cara merencanakan, mencatat pelaksanaan, dan mengevaluasi pelaksanaan dari luar arena kelas; jadi dalam penelitian jenis ini, peneliti harus berkolaborasi dengan guru yang melaksanakan tindakan dalam kelas.

Suatu PTK dikategorikan sebagai PTK eksperimental jika PTK dilaksanakan dengan cara menerapkan berbagai teknik, metode, dan atau strategi dalam proses pembelajaran secara efektif dan efisien. Dalam kaitannya dengan proses pembelajaran, teknik dan atau strategi yang diterapkan dimungkinkan terdapat lebih dari satu strategi atau teknik yang dipilih untuk mencapai tujuan pembelajaran. Melalui PTK eksperimen, diharapkan peneliti dapat menentukan cara atau strategi mana yang paling efektif dalam rangka pencapaian tujuan pembelajaran.

Sampai saat ini, ada beberapa model PTK yang sering diterapkan dalam dunia pendidikan, seperti (a) model Kurt Lewin, (b) model Kemmis dan Mc Taggart, (c) model John Elliot, dan (d) model Dave Ebbutt. Meskipun demikian, secara garis besar terdapat empat tahapan yang lazim dilalui dalam PTK yaitu: tahap perencanaan (planning), tahap pelaksanaan (acting), tahap pengamatan (observation), dan tahap refleksi (reflection). Empat langkah dalam satu siklus yang dikemukakan oleh Lewin tersebut oleh Stringer (2004) dielaborasi menjadi tiga langkah saja yakni: perencanaan (planning), pelaksanaan (implementing), dan penilaian (evaluation). Model dan penjelasan untuk masing-masing tahap sebagaimana tampak pada gambar-1.

\section{Tahap-1. Perencanaan Tindakan}

Dalam tahap ini, peneliti menjelaskan tentang: apa, mengapa, kapan, di mana, oleh siapa, dan bagaimana tindakan tersebut dilakukan. Penelitian tindakan yang ideal sebetulnya dilakukan secara berpasangan antara pihak yang melakukan tindakan (guru mitra) dengan pihak yang mengamati proses jalannya tindakan (peneliti). Cara ini dikatakan ideal, karena adanya upaya untuk mengurangi unsur subjektivitas pengamat serta mutu kecermatan terhadap aspek-aspek yang diamati. Namun demikian, apabila 
penelitian dilaksanakan sendiri oleh guru sebagai peneliti, maka instrumen pengamatan harus disiapkan secara cermat disertai dengan lembar catatan lapangan (field note). Yang perlu diingat bahwa pengamatan yang dilakukan terhadap diri sendiri biasanya kurang teliti jika dibanding dengan pengamatan yang dilakukan oleh orang lain. Dalam pelaksanaan pembelajaran, rencana tindakan dalam rangka PTK perlu dituangkan dalam bentuk RPP (Rencana Pelaksanaan Pembelajaran).

Tahap-2. Pelaksanaan Tindakan

Tahap ke-2 dari PTK adalah pelaksanaan, yaitu implementasi atau penerapan isi rencana tindakan dalam kelas yang diteliti. Hal yang perlu diingat bahwa dalam tahap-2 ini pelaksana (guru) harus ingat dan berusaha mentaati apa yang sudah dirumuskan dalam rencana tindakan; dilakukan secara wajar, tidak kaku, dan tidak dibuat-buat.

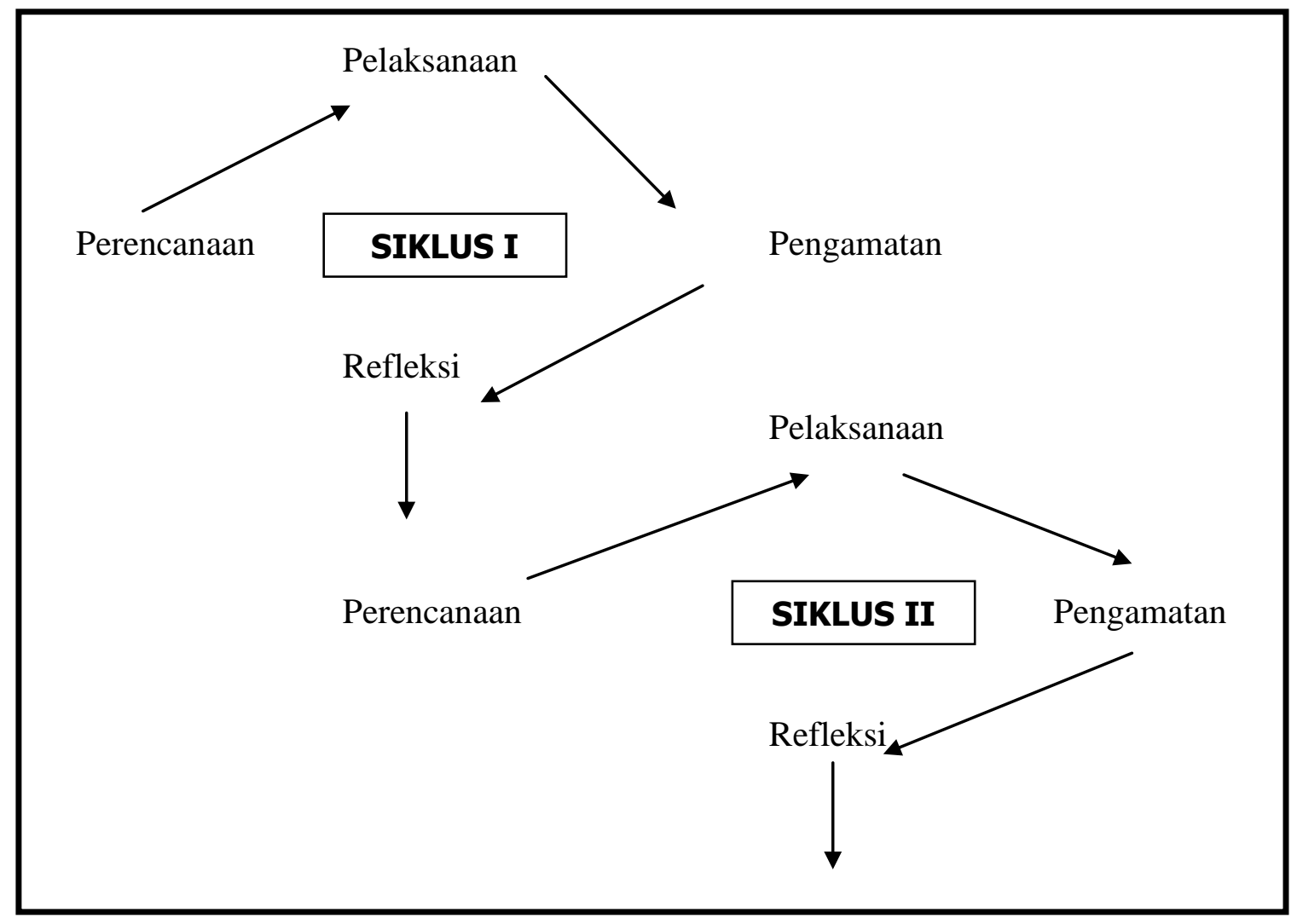

Gambar-1. Alur Penelitian Tindakan Kelas 


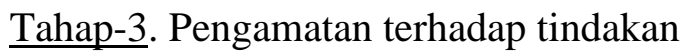

Tahap ke-3, yaitu kegiatan pengamatan yang dilakukan oleh pengamat (peneliti atau guru). Seperti telah dijelaskan sebelumnya bahwa kegiatan pengamatan ini tidak terpisah dari kegiatan pelaksanaan tindakan; karena pengamatan dilakukan pada waktu tindakan sedang dilakukan; jadi kedua kegiatan (pelaksanaan tindakan dan pengamatan) berlangsung dalam waktu yang sama. Sebutan tahap-2 dan tahap-3 dimaksudkan untuk memberikan peluang kepada guru pelaksana yang berstatus pula sebagai pengamat (ketika sedang melakukan tindakan, tentu tidak sempat menganalisis peristiwa yang terjadi).

Tahap-4. Refleksi terhadap tindakan

Tahap ke-4 merupakan kegiatan untuk mengemukakan kembali apa yang telah dilakukan. Istilah 'refleksi' (Inggris: reflection) bisa diterjemahkan dalam bahasa Indonesia 'pemantulan'. Kegiatan refleksi lebih tepat dikerjakan ketika guru pelaksana telah selesai melakukan tindakan, kemudian berhadapan dengan peneliti untuk mendiskusikan hasil implementasi dari rancangan tindakan. Dan inilah inti dari penelitian tindakan, yakni ketika guru pelaku tindakan mengatakan kepada peneliti mengenai hal-hal yang dirasakan sudah berjalan baik, dan bagian mana yang belum baik. Apabila guru pelaksana tindakan juga berstatus sebagai pengamat, maka refleksi dilakukan terhadap diri sendiri, dalam arti guru tersebut melihat dirinya sendiri, melakukan 'dialog' untuk menemukan hal-hal yang telah dirasakan memuaskan, dan mengenali hal-hal yang masih perlu diperbaiki. Dalam hal seperti ini, maka guru tersebut melakukan 'self evaluation' yang diharapkan dilakukan secara objektif. Untuk menjaga objektivitas tersebut, seringkali hasil refleksi itu diperiksa ulang atau divalidasi oleh orang lain, misalnya teman sejawat yang diminta untuk mengamati. Jadi pada intinya, kegiatan refleksi adalah kegiatan evaluasi, analisis, pemaknaan, penjelasan, penyimpulan, dan identifikasi sebagai bahan tindak lanjut dalam perencanaan tindakan pada siklus berikutnya.

Keempat tahap dalam PTK tersebut merupakan unsur-unsur yang membentuk sebuah siklus, yaitu satu putaran kegiatan secara beruntun, dari tahap penyusunan 
rancangan sampai dengan refleksi. Dengan demikian, PTK tidak pernah merupakan kegiatan tunggal, akan tetapi selalu berupa serangkaian kegiatan yang akan kembali ke asal, dalam bentuk siklus-siklus.

\section{Sasaran Penelitian Tindakan Kelas}

Hal-hal yang dapat diteliti dalam PTK berhubungan dengan setiap unsur dalam proses pembelajaran. Sesuai dengan prinsip bahwa dalam PTK terdapat tindakan yang dirancang sebelumnya, maka objek PTK harus merupakan sesuatu yang bersifat aktif atau sesuatu yang dikenai aktivitas tersebut; bukan objek yang sedang dalam keadaan diam, tanpa bergerak. Menurut Sulipan (2008) objek yang dapat diteliti melalui PTK dapat dikelompokkan menjadi sejumlah unsur yakni (1) unsur siswa, (2) unsur guru, (3) unsur materi pembelajaran, (4) unsur peralatan atau sarana pembelajaran, (5) unsur hasil pembelajaran, (6) unsur lingkungan, dan (7) unsur pengelolaan.

Dari unsur siswa yang dapat dicermati objeknya antara lain ketika siswa yang bersangkutan sedang asyik mengikuti proses pembelajaran di kelas atau di laboratorium, atau di bengkel atau di lapangan, maupun ketika siswa sedang asyik mengerjakan kerja bakti di luar sekolah, atau ketika siswa sedang terlibat dalam kegiatan ekstrakurikuler.

Unsur guru yang dapat diteliti misalnya ketika guru sedang mengajar di kelas, sedang membimbing siswa yang berdarmawisata, atau ketika guru sedang mengadakan kunjungan ke rumah siswa.

Unsur materi pelajaran yang dapat diteliti antara lain urutan materi ketika disajikan kepada siswa, pengorganisasiannya, cara penyajiannya, atau cara pengaturannya.

Unsur peralatan atau sarana pembelajaran meliputi semua peralatan, baik yang dimiliki siswa secara perorangan atau peralatan yang disediakan oleh sekolah, atauun peralatan yang digunakan di dalam kelas dan cara penggunaannya.

Unsur hasil pembelajaran dapat ditinjau dari tiga ranah untuk dijadikan titik tujuan yang harus dicapai melalui proses pembelajaran, baik susunan maupun tingkat pencapaiannya. Oleh sebab itu, hasil belajar merupakan produk yang harus ditingkatkan dan hal itu terkait dengan tindakan terhadap unsur yang lainnya. 
Unsur lingkungan, baik lingkungan siswa di kelas, di sekolah, maupun yang melingkungi siswa di rumahnya. Informasi tentang lingkungan ini dikaji bukan untuk dilakukan campur tangan, akan tetapi digunakan sebagai pertimbangan dan bahan untuk pembahasan.

Unsur pengelolaan yang diteliti hendaknya jelas-jelas merupakan gerak kegiatan sehingga mudah diatur dan direkayasa dalam bentuk tindakan antara lain cara mengelompokkan siswa ketika guru memberikan tugas, pengaturan urutan jadwal, pengaturan tempat duduk, penempatan papan tulis, penataan peralatan milik siswa, dan sebagainya.

\section{Merencanakan Penelitian Tindakan Kelas}

Seperti halnya penelitian (research) pada umumnya, ada beberapa langkah yang hendaknya diikuti dalam merencanakan PTK. Mundilarto (2004) menyarankan langkahlangkah dalam perencanaan PTK meliputi (1) mengidentifikasi dan merumuskan masalah, (2) menganalisis masalah, (3) merumuskan hipotesis tindakan, (4) membuat rencana tindakan dan pemantauannya, (5) melaksanakan tindakan dan mengamatinya, (6) mengolah dan menafsirkan data, dan (7) melaporkan.

\section{Identifikasi dan merumuskan masalah}

Sebagaimana telah diungkapkan sebelumnya bahwa PTK yang dilakukan oleh guru ditujukan untuk mengubah perilaku guru itu sendiri, perilaku teman sejawat, dan perilaku siswa -mengubah kerangka kerja, proses pembelajaran, yang pada gilirannya menghasilkan perubahan pada guru dan siswa. Dengan perkataan lain, PTK dilakukan untuk meningkatkan praktik pembelajaran dalam kelas. Contoh-contoh bidang garapan PTK antara lain (a) metode pembelajaran; mungkin mengganti metode pembelajaran konvensaional dengan metode pembelajaran yang dapat mengaktifkan siswa, bersifat inovatif, membangkitkan kreativitas dan dapat menimbulkan suasana yang menyenangkan; (b) strategi pembelajaran; mungkin menggunakan pendekatan pembelajaran yang bersifat integratif, bukan hanya dengan satu gaya mengajar saja; (c) prosedur evaluasi; misalnya meningkatkan metode dalam penilaian yang bersfat outentik 
dan atau penggunaan portofolio; (d) penanaman sikap dan nilai; mungkin mendorong munculnya sikap yang lebih positif terhadap berbagai aspek kehidupan -kebiasaan membuang sampah, menghormat dan santun kepada orang yang lebih tua; (e) pengembangan profesional guru; pembelajaran yang baru, menambah kemampuan menganalisis, atau meningkatkan kesadaran diri; (f) administrasi dan manajemen; misalnya meningkatkan efisiensi aspek tertentu dalam administrasi sekolah.

Seperti halnya dalam penelitian jenis lain, langkah perama dalam PTK adalah mengidentifikasi masalah. Masalah yang akan diteliti harus dirasakan dan diidentifikasi oleh peneliti sendiri bersama kolaborator, --meskipun bisa dengan bantuan seorang fasilitator, --agar supaya mereka betul-betul terlibat dalam proses penelitiannya. Masalah yang diteliti bisa berupa: kekurangan yang dirasakan dalam pengetahuan, keterampilan, sikap, etos kerja, kelancaran berkomunikasi, kreativitas, dsb; yang pada dasarnya berupa kesenjangan atau jarak antara apa yang diinginkan, apa yang diharapkan, apa yang dicita-citakan dengan kenyataan atau realitas yang dialami.

Beberapa kriteria dalam menentuan masalah antara lain (a) masalah harus penting bagi orang yang mengusulkan dan sekaligus signifikan dilihat dari segi pengembangan lembaga atau program, (b) masalah hendaknya dalam jangkauan penanganan, (c) pernyataan masalah harus mengungkapkan beberapa dimensi fundamental mengenai faktor penyebab sehingga pemecahannya dapat dilakukan berdasarkan hal-hal fundamental tersebut.

\section{Menganalisis masalah}

Analisis masalah perlu dilakukan untuk mengetahui dimensi-dimensi masalah yang mungkin ada untuk mengidentifikasi aspek-aspek penting dan memberikan penekanan pada hal-hal tertentu. Analisis masalah melibatkan beberapa jenis kegiatan, tergantung pada kesulitan yang ditunjukkan dalam pertanyaan masalahnya. Analisis sebab-akibat tentang kesulitan yang dihadapi atau untuk mengubah perspektif orangorang yang terlibat dalam penelitian. Kegiatan-kegiatan tersebut dapat dilakukan melalui diskusi di antara para peneliti dengan kolaboratornya.

Tabel-1. Contoh Masalah Penelitian PTK dan Rumusannya 


\begin{tabular}{|r|l|l|}
\hline No. & \multicolumn{1}{|c|}{ Masalah } & \multicolumn{1}{|c|}{ Rumusan Masalah } \\
\hline 1. & $\begin{array}{l}\text { Rendahnya kemampuan mahasiswa } \\
\text { mengajukan pertanyaan kritis }\end{array}$ & $\begin{array}{l}\text { Mahasiswa semester-5 mestinya mampu } \\
\text { mengajukan pertanyaan yang kritis, } \\
\text { tetapi dalam kenyataannya pertanyaan } \\
\text { mereka lebih bersifat klasifikasi }\end{array}$ \\
\hline 2. & $\begin{array}{l}\text { Rendahnya ketaatan staf pada perintah } \\
\text { atasan }\end{array}$ & $\begin{array}{l}\text { Staf di kantor mestinya melakukan apa } \\
\text { yang diperintahkan atasannya, tetapi } \\
\text { dalam kenyataannya mereka sering } \\
\text { melakukan hal-hal yang tidak } \\
\text { diperintahkan }\end{array}$ \\
\hline 3. & $\begin{array}{l}\text { Rendahnya keterlibatan siswa dalam } \\
\text { proses pembelajaran Bhs Inggris }\end{array}$ & $\begin{array}{l}\text { Siswa mestinya terlibat secara aktif } \\
\text { dalam kegiatan pembelajaran bahasa } \\
\text { Inggris, terapi dalam kenyataannya } \\
\text { mereka sangat pasif }\end{array}$ \\
\hline 4. & $\begin{array}{l}\text { Rendahnya kualitas proses } \\
\text { pembelajaran bahasa Indonesia }\end{array}$ & $\begin{array}{l}\text { Proses pembelajaran mestinya } \\
\text { memberikan kesempatan kepada siswa } \\
\text { untuk belajar menggunakan bahasa } \\
\text { secara komunikatif, tetapi dalam } \\
\text { kenyataannya kegiatan pembelajaran } \\
\text { terbatas pada kosakata, lafal, dan } \\
\text { struktur }\end{array}$ \\
\hline 5. & $\begin{array}{l}\text { Kenadirian belajar siswa SMA mestinya } \\
\text { telah berkembang jika kegatan } \\
\text { belajarnya mendukung, tetapi dalam } \\
\text { kenyataannya dominasi peran guru telah } \\
\text { menghambat perkembangannya }\end{array}$ \\
\hline
\end{tabular}

Sumber: Suwarsih Madya, 2008

3. Merumuskan hipotesis tindakan

Hipotesis penelitian dalam penelitian tindakan bukan hipotesis yang menyatakan ada perbedaan nilai atau hubungan antarvariabel; melainkan berupa hipotesis tindakan. Idealnya, hipotesis penelitian tindakan mendekati keketatan penelitian formal, akan tetapi situasi lapangan yang senantiasa berubah membuatnya sulit untuk memenuhi tuntutan itu.

Rumusan hipotesis dalam penelitian tindakan memuat tindakan yang diusulkan untuk menghasilkan perbaikan yang diinginkan. Untuk sampai pada pemilihan tindakan yang dianggap tepat, peneliti dapat mulai dengan menimbang prosedur-prosedur yang 
mungkin dapat dilakukan agar perbaikan yang diinginkan dapat dicapai sampai menemukan prosedur tindakan yang dianggap tepat. Dalam menimbang-nimbang berbagai prosedur ini, sebaiknya peneliti mencari masukan dari teman sejawat atau mencari 'ilham' dari teori dan atau hasil penelitian sebelumnya sehingga rumusan hipotesisnya akan lebih tepat. Contoh rumusan hipotesis tindakan sesuai rumusan masalah pada tabel-1 dapat dicermati melalui tabel-2 berikut.

Tabel-2. Contoh Rumusan Hipotesis Tindakan Berdasarkan Rumusan Masalah

\begin{tabular}{|c|c|c|}
\hline No. & Rumusan Masalah & Hipotesis Tindakan \\
\hline 1. & $\begin{array}{l}\text { Mahasiswa semester-5 mestinya } \\
\text { mampu mengajukan pertanyaan yang } \\
\text { kritis, tetapi dalam kenyataannya } \\
\text { pertanyaan mereka lebih bersifat } \\
\text { klasifikasi }\end{array}$ & $\begin{array}{l}\text { Jika tingkat kekritisan pertanyaan } \\
\text { mahasiswa dijadikan penilaian kualitas } \\
\text { partisipasi mereka, setelah diberi } \\
\text { contoh, maka kemampuan mengajukan } \\
\text { pertanyaan kritis mereka akan } \\
\text { meningkat }\end{array}$ \\
\hline 2. & $\begin{array}{l}\text { Staf di kantor mestinya melakukan apa } \\
\text { yang diperintahkan atasannya, tetapi } \\
\text { dalam kenyataannya mereka sering } \\
\text { melakukan hal-hal yang tidak } \\
\text { diperintahkan }\end{array}$ & $\begin{array}{l}\text { Jika diterapkan sanksi terhadap } \\
\text { ketidaktaatan terhadap perintah atasan, } \\
\text { ketaatan staf terhadap perintah atasan } \\
\text { akan meningkat }\end{array}$ \\
\hline 3. & $\begin{array}{l}\text { Siswa mestinya terlibat secara aktif } \\
\text { dalam kegiatan pembelajaran bahasa } \\
\text { Inggris, terapi dalam kenyataannya } \\
\text { mereka sangat pasif }\end{array}$ & $\begin{array}{l}\text { Melalui kegiatan yang menyenangkan } \\
\text { dalam belajar menggunakan bahasa } \\
\text { Inggris, keterlibatan siswa dalam } \\
\text { pembelajaran akan meningkat }\end{array}$ \\
\hline 4. & $\begin{array}{l}\text { Proses pembelajaran mestinya } \\
\text { memberikan kesempatan kepada siswa } \\
\text { untuk belajar menggunakan bahasa } \\
\text { secara komunikatif, tetapi dalam } \\
\text { kenyataannya kegiatan pembelajaran } \\
\text { terbatas pada kosakata, lafal, dan } \\
\text { struktur }\end{array}$ & $\begin{array}{l}\text { Jika pembelajaran difokuskan pada } \\
\text { pengembangan kompetensi komunikatif } \\
\text { berbahasa Inggris, kualitas proses } \\
\text { pembelajaran akan meningkat }\end{array}$ \\
\hline 5. & $\begin{array}{l}\text { Kenadirian belajar siswa SMA } \\
\text { mestinya telah berkembang jika } \\
\text { kegatan belajarnya mendukung, tetapi } \\
\text { dalam kenyataannya dominasi peran } \\
\text { guru telah menghambat } \\
\text { perkembangannya }\end{array}$ & $\begin{array}{l}\text { Jika kegiatan pembelajaran diciptakan } \\
\text { untuk memenuhi kebutuhan } \\
\text { perkembangan masing-masing siswa, } \\
\text { kemandirian belajar siswa akan } \\
\text { meningkat }\end{array}$ \\
\hline
\end{tabular}
Sumber: Suwarsih Madya, 2008 
Untuk langkah-4 (membuat rencana tindakan dan pemantauannya) dan langkahlangkah selanjutnya telah dijelaskan pada bagian Jenis dan Model PTK serta akan dikaji dalam makalah lain.

\section{Instrumen untuk Mengukur Keberhasilan Tindakan}

Instrumen yang diperlukan dalam PTK haruslah sejalan dengan prosedur dan langkah-langkah PTK. Menurut Herawati Susilo dan Kisyani Laksono (2008) instrumen yang digunakan untuk mengukur tingkat keberhasilan tindakan dapat dipahami dari dua sisi, yakni sisi proses pengamatan, dan sisi hal yang diamati.

Dari sisi proses -bagan alir--, instrumen dalam PTK harus dapat menjangkau masalah yang berkaitan dengan input (kondisi awal), proses (saat berlangsung), dan output (hasil). Instrumen untuk input dapat dikembangkan dari hal-hal yang menjadi akar masalah beserta pendukungnya. Misalnya, jika akar masalah adalah kemampuan awal siswa dianggap kurang; dalam hal ini tes kemampuan awal dapat menjadi instrumen yang tepat. Instrumen yang digunakan pada saat proses pembelajaran berlangsung berkaitan erat dengan tindakan yang dipilih. Dalam tahap ini banyak format yang tersedia, akan tetapi format yang digunakan hendaknya sesuai dengan tindakan yang dipilih. Instrumen untuk output berkaitan erat dengan evaluasi pencapaian hasil berdasarkan kriteria dan atau indikator yang telah ditetapkan. Misalnya, nilai 75 ditetapkan sebagai ambang batas peningkatan, maka pencapaian hasil yang sampai pada angka 75 perlu untuk dilakukan tindakan lagi -ada siklus berikutnya.

Selain dari sisi proses, instrumen PTK dapat pula dipahami dari sisi hal yang diamati. Menurut Reed dan Bergermann (1992), ditinjau dari hal yang diamati, instrumen dapat dikelompokkan menjadi tiga jenis, yaitu: instrumen untuk mengamati guru (observing teachers), instrumen untuk mengamati kelas (observing classroom), dan instrumen untuk mengamati perilaku siswa (observing students). Instrumen yang digunakan untuk mengamati guru merupakan alat yang terbukti efektif untuk mempelajari metode dan strategi yang diimplementasikan guru di kelas, misalnya: 
pengelolaan kelas, kemampuan guru menerapkan metode pembelajaran tertentu, atau keterampilan mengajar lainnya, yang memuat secara rinci peristiwa yang terjadi di kelas berdasarkan sekuensi (urutan kronologis) mulai dari membuka pelajaran, menjelaskan, melakukan variasi, mengajukan pertanyaan, sampai pada kegiatan menutup pelajaran. Instrumen untuk mengamati kelas sangat bermanfaat karena dapat mengungkapkan praktik-praktik pembelajaran yang menarik dalam kelas. Di samping itu, pengamatan ini juga dapat menunjukkan strategi yang digunakan guru dalam menangani hambatan dan kendala pembelajaran yang terjadi. Catatan kelas meliputi deskripsi tentang lingkungan fisik kelas, tata letak, dan manajemen kelas. Instrumen untuk siswa digunakan untuk mengamati perilaku siswa secara individual atau berkelompok sebelum, saat berlangsung, dan setelah selesai pembelajaran. Perubahan setiap individu diamati dalam durasi waktu tertentu, mulai dari sebelum dilakukan tindakan, pada saat implementasi tindakan, dan setelah tindakan.

Di samping lembar pengamatan, --dari sisi proses dan hal yang diamatiinstrumen lain yang dapat digunakan dalam pengumpulan data dalam PTK antara lain: pedoman wawancara, kuesioner, pengkajian data dokumen, dan tes.

Untuk memperoleh informasi yang lebih rinci dan untuk melengkapi data hasil pengamatan, tim peneliti dapat melakukan wawancara kepada guru, siswa, kepala sekolah, dan fasilitator yang berkolaborasi. Wawancara digunakan untuk mengungkap data yang berhubungan dengan sikap, pendapat, atau wawasan. Wawancara dapat dilakukan secara bebas dan terstruktur dalam situasi wajar, dan informal. Wawancara hendaknya dilakukan dengan menggunakan pedoman wawancara agar semua informasi dapat diperoleh secara lengkap. Guru mitra dapat pula berperan sebagai pewawancara terhadap siswanya, akan tetapi harus dapat menjaga agar hasil wawancara memiliki objektivitas yang tinggi. Kuesioner dapat dikembangkan berdasarkan permasalahan yang ingin digali, misalnya tanggapan siswa tentang penerapan model pembelajaran yang baru diikuti, atau bagaimana jika model tersebut diterapkan pada pokok bahasan yang lain. Pengkajian data melalui dokumen dapat berupa: daftar hadir, silabus, RPP, hasil karya siswa, hasil karya guru, lembar kerja, dan sebagainya. Pengambilan data yang 
berkaitan dengan pengetahuan, bakat, dan hasil belajar dapat dilakukan melalui tes dan asesmen (Tim PGSM, 1999; Mills, 2003).

\section{Daftar Pustaka}

Herawati Susilo dan Kisyani Laksono. (2008). Implementasi Penelitian Tindakan Kelas. diambil dari http://www.ekofeum.or.id/artikel.php?.cid=26 tanggal 15 Mei 2008.

Mills, Geoffrey. (2003). Action Research: A Guide for the Teacher Research. New Jersey: Prentice Hall.

Mundilarto, Rustam. (2004). Penelitian Tindakan Kelas. Jakarta: Direktorat Pembinaan Pendidikan Tenaga Kependidikan dan Ketenagaan Perguruan Tinggi, Ditjendikti, Depdiknas.

Reed, A.J.S. and Bergermann, V.E. (1992). A Guide to Observation and Participation in the Classroom. Connecticut: The Dushkin Publishing Group, Inc.

Sulipan. (2008). Penelitian Tindakan Kelas. diambil dari http://www.profesiguru.com/ pdf/penelitian\%20tindakan\%20kelas-siln\%20dan\%20kti.pdf. tanggal 17 Mei 2008.

Sunendar, Tatang. (2008). Penelitian Tindakan Kelas (Part II). diambil dari http:// www.akhmadsudrajat.wordpress.com/2008/03/21/penelitian-tindakan-kelas-partii tanggal 15 Mei 2008 .

Suwarsih Madya. (2008). Penelitian Tindakan Kelas (Bagian III). diambil dari http:// www.ktiguru.org/index.php/ptk-3/part-iii. tanggal 15 Mei 2008.

Stringer, Ernest. (2004). Action Research in Education. Columbus: Pearson, Menvi Prentice Hall.

Tim PGSM. (1999). "Penelitian Tindakan Kelas", Bahan Pelatihan Dosen LPTK dan Guru Sekolah Menengah. Jakarta: Proyek PGSM, Dikti.

Sanjaya. (2008). Judul Proposal Penelitian Tindakan Kelas. diambil dari http://www. idtesis/referensi-skripsi-tesis-disertasi. tanggal 17 Mei 2008.

Lampiran: Contoh Judul-judul Proposal Penelitian Tindakan Kelas

No. Judul Penelitian 


\begin{tabular}{|c|c|}
\hline 1. & $\begin{array}{l}\text { Upaya Meningkatkan Motivasi Belajar Siswa SD melalui Peranan Hadiah } \\
\text { sebagai Perangsang Timbulnya Kompetisi }\end{array}$ \\
\hline 2. & Upaya Meningkatkan Kedisiplinan siswa Melalui Penerapan Hukuman \\
\hline 3. & $\begin{array}{l}\text { Upaya Meminimalkan Miskonsepsi dan Meningkatkan Pemahaman Konsep- } \\
\text { konsep IPA bagi Siswa Kelas IV SD melalui Pembelajaran Konstruktivistik }\end{array}$ \\
\hline 4. & $\begin{array}{l}\text { Meningkatkan Prestasi Belajar IPA di SD dengan Pendekatan Keterampilan } \\
\text { Proses }\end{array}$ \\
\hline 5. & Mengatasi Kesulitan Belajar Siswa melalui Pemberian Bimbingan Belajar di SD \\
\hline 6. & Peningkatan Kedisiplinan Siswa melalui Keteladanan Guru SD \\
\hline 7. & $\begin{array}{l}\text { Meningkatkan Pembelajaran Fisika pada SMP melalui Optimalisasi Kegiatan } \\
\text { Laboratorium Berbasis Cooperative Learning }\end{array}$ \\
\hline 8. & $\begin{array}{l}\text { Upaya Mengaktifkan Siswa dalam Pembelajaran Matematika di SD melalui } \\
\text { Pendekatan Realistik }\end{array}$ \\
\hline 9. & $\begin{array}{l}\text { Peningkatan Kualitas Proses dan Hasil Pembelajaran Matematika di SD melalui } \\
\text { Penggunaan Alat Peraga Secara Efektif }\end{array}$ \\
\hline 10. & $\begin{array}{l}\text { Upaya Menumbuhkan Bakat dan Kreativitas Siswa Kelas IV SD dalam } \\
\text { Pembelajaran Matematika melalui Metode Discovery Learning }\end{array}$ \\
\hline 11. & $\begin{array}{l}\text { Meningkatkan Kemampuan Menulis Karangan Bahasa Indonesia Siswa Kelas } \\
\text { IV SD dengan Mengefektifkan Penggunaan Media Gambar Seri }\end{array}$ \\
\hline 12. & $\begin{array}{l}\text { Upaya Mengoptimalkan Bimbingan Konseling di SD untuk Mengatasi } \\
\text { Kesulitan Belajar Anak }\end{array}$ \\
\hline 13. & Keefektifan Pembelajaran Bahasa Indonesia dengan Pendekatan Komunikatif \\
\hline 14. & $\begin{array}{l}\text { Penerapan Pembelajaran Terpadu dalam Meningkatkan Kemampuan Berbahasa } \\
\text { Siswa Kelas II SD }\end{array}$ \\
\hline 15. & $\begin{array}{l}\text { Penerapan Konsep Pelajaran PPKn melalui Model Pembelajaran Berbasis } \\
\text { Portofolio dengan Pendekatan Sains Teknologi Masyarakat }\end{array}$ \\
\hline 16. & $\begin{array}{l}\text { Upaya Menimbulkan Keantusiasan Siswa dalam Pembelajaran Apresiasi Sastra } \\
\text { Indonesia di SD melalui Metode Quantum Teaching }\end{array}$ \\
\hline
\end{tabular}

Sumber: http://www.idtesis/referensi-skripsi-tesis-disertasi 